\title{
Regional and annual variation in black-legged kittiwake breeding productivity is related to sea surface temperature
}

\author{
Morten Frederiksen ${ }^{1,4, *}$, Martin Edwards ${ }^{2}$, Roderick A. Mavor ${ }^{3}$, Sarah Wanless ${ }^{1}$ \\ ${ }^{1}$ Centre for Ecology and Hydrology, Hill of Brathens, Banchory AB31 4BW, UK \\ ${ }^{2}$ Sir Alister Hardy Foundation for Ocean Science, The Laboratory, Citadel Hill, Plymouth PL1 2PB, UK \\ ${ }^{3}$ Joint Nature Conservation Committee, Dunnet House, 7 Thistle Place, Aberdeen AB10 1UZ, UK \\ ${ }^{4}$ Present address: National Environmental Research Institute, Dept. of Arctic Environment, University of Aarhus, \\ Frederiksborgvej 399, 4000 Roskilde, Denmark
}

\begin{abstract}
Spatiotemporal variation in seabird demographic parameters is often pronounced and may be an important source of information on the state of marine ecosystems. Black-legged kittiwakes Rissa tridactyla in Britain and Ireland show strong regional structure in breeding productivity, and both temporal and spatial variation are probably related to abundance of the principal prey of breeding kittiwakes, the lesser sandeel Ammodytes marinus. Annual regional estimates of sandeel abundance do not exist, prohibiting direct tests of this hypothesis. We examined relationships between kittiwake breeding productivity and 2 potential proxies of sandeel abundance, winter sea surface temperature (SST) and abundance of Calanus copepods, within and among 6 regions in Britain and Ireland from 1986 to 2004. Means and trends in winter SST differed among regions, with higher means and less pronounced increasing trends in western (Atlantic) regions than in eastern (North Sea) regions. A negative relationship between breeding productivity and winter SST in the previous year was found within 2 regions (East Scotland and Orkney), as well as in a cross-regional analysis. Results were inconclusive for Calanus abundance, with a positive relationship in East Scotland and negative in Orkney. These results demonstrate that although a single environmental driver (SST) is related to both within- and between-region variation in a key demographic parameter, regional heterogeneity in SST trends as well as the importance of other factors may lead to highly variable responses. Understanding this heterogeneity is critical for predicting long-term effects of climate change or other anthropogenic drivers on marine ecosystems.
\end{abstract}

KEY WORDS: Kittiwakes · Spatial population dynamics $\cdot$ Ocean climate $\cdot$ Seabirds $\cdot$ Sandeels $\cdot$ Rissa tridactyla $\cdot$ Ammodytes marinus

- Resale or republication not permitted without written consent of the publisher

\section{INTRODUCTION}

Seabirds often show pronounced spatiotemporal variation in population growth rates and demographic parameters (Tims et al. 2004, Harris et al. 2005, Lewis et al. 2006, Suryan et al. 2006). This variation is likely to be linked to variation in e.g. food supply around breeding colonies, and is potentially a useful source of information about the state of marine ecosystems. Seabird species differ in their sensitivity to variation in abiotic or biotic conditions, and also in how easy they are to study; some species are therefore particularly suitable as indicators or research subjects in marine ecology. Because of their high foraging costs, blacklegged kittiwakes Rissa tridactyla (hereafter kittiwakes) are regarded as very sensitive to changes in prey availability (Furness \& Tasker 2000), and they have repeatedly been shown to be good indicators of the state of marine environments, with various aspects of breeding performance being well correlated with e.g. oceanographic variables, prey abundance and fishery activity (Regehr \& Montevecchi 1997, Suryan et al. 2002, Wanless et al. 2007). Kittiwake breeding populations have declined dramatically $(>50 \%)$ since 
1990 in large parts of the British Isles, but have remained stable or increased in other areas (Mavor et al. 2006), and understanding the underlying causes of this geographical variation in population trends is important for managing both seabird populations and marine ecosystems. Frederiksen et al. (2004) showed that breeding productivity in 1 North Sea kittiwake colony (the Isle of May) was negatively related to late winter sea surface temperature (SST) in the previous year and the presence of a fishery for lesser sandeels Ammodytes marinus (hereafter sandeels), the main prey of breeding kittiwakes (Lewis et al. 2001). Furthermore, kittiwake breeding productivity was well correlated over time within, but not among, 6 regions in Britain and Ireland, and these regions were congruent with sandeel population structure inferred from patterns of occurrence of larvae and adult sandeels (Frederiksen et al. 2005). The aim of this paper was to examine whether there is evidence that variation in kittiwake breeding productivity within and among the regions identified by Frederiksen et al. (2005) is related to sandeel abundance. Regionally explicit annual estimates of sandeel abundance do not exist, and it is thus not possible to directly test whether such a relationship exists. However, 2 potential proxies of sandeel abundance are available: winter SST, which



Fig. 1. Rissa tridactyla. Regions and colonies included in this study is negatively correlated with sandeel recruitment in the southern North Sea (Arnott \& Ruxton 2002, cf. Hedd et al. 2006), and the Continuous Plankton Recorder (CPR) survey (Reid et al. 2003), which measures abundance of Calanus copepods, an important prey of sandeels (Reay 1986). Recent exploratory analyses at the North Sea scale confirmed that sandeel recruitment was negatively correlated with winter SST, and also found a positive correlation with Calanus abundance (ICES 2006). While SSTs have increased everywhere in the NE Atlantic in recent years, there has been pronounced regional variation, with more rapid increases in the North Sea than west of the British Isles (Edwards et al. 2006). Also in the North Sea, Calanus abundance has decreased, and there has been a shift in species composition, with the formerly dominant spring-blooming $C$. finmarchicus being gradually replaced by $C$. helgolandicus, which occurs later in the year (Edwards et al. 2004). Here, we tested whether annual variation in kittiwake breeding productivity within 6 regions of the British Isles defined by Frederiksen et al. (2005) is related to winter SST and/or Calanus abundance. We also tested whether between-region variation in kittiwake breeding productivity and population growth is related to the same environmental covariates.

\section{MATERIALS AND METHODS}

Frederiksen et al. (2005) assigned monitored kittiwake colonies in Britain and Ireland to 6 geographically contiguous regions (Fig. 1) based on similar temporal fluctuations in breeding productivity. Breeding productivity (mean number of fledged chicks per nest) is monitored at a large number of colonies using highly standardised methods (Walsh et al. 1995) as part of the Seabird Monitoring Programme coordinated by the UK Joint Nature Conservation Committee. We used data from 48 British and Irish kittiwake colonies regularly monitored from 1986 to 2004. In addition to 40 out of 42 colonies listed by Frederiksen et al. (2005) that were assigned to a region, we included data from 8 further colonies: Noness and Kettlaness in the Shetland region, as well as Contrary Head on the Isle of Man, St. Bee's Head in Cumbria, Isle of Muck and Rathlin in Northern Ireland, and Rockabill and Helvick Head in the Irish Republic, all of which we assigned to the Irish Sea region (Fig. 1). Throughout, we assumed that kittiwakes mainly depend on 1-yr-old sandeels for successful breeding (Frederiksen et al. 2004, Wanless et al. 2007) and that a strong year class of 0-group sandeels will lead to high availability to kittiwakes in the following year. Our covariates were defined according to these assumptions. SST in February and March of the 
Table 1. Means and linear trends of mean February/March sea surface temperatures (SST) in 6 regions around the British Isles, 1985 to 2003 (lagged by 1 yr relative to kittiwake breeding productivity data)

\begin{tabular}{|lccccc|}
\hline Region & Latitude & Longitude & $\begin{array}{c}\text { Mean SST } \\
\left({ }^{\circ} \mathrm{C}\right)\end{array}$ & $\begin{array}{c}\text { Trend } \\
\left({ }^{\circ} \mathrm{C} \mathrm{yr}^{-1}\right)\end{array}$ & $\begin{array}{c}\mathrm{p} \text { of } \\
\text { trend }\end{array}$ \\
\hline West Scotland & $56^{\circ}-59^{\circ} \mathrm{N}$ & $5^{\circ}-10^{\circ} \mathrm{W}$ & 8.64 & 0.0065 & 0.67 \\
Shetland & $59^{\circ} 30^{\prime}-61^{\circ} 30^{\prime} \mathrm{N}$ & $1^{\circ} \mathrm{E}-2^{\circ} 30^{\prime} \mathrm{W}$ & 7.53 & 0.020 & 0.19 \\
Orkney & $58^{\circ} 30^{\prime}-59^{\circ} 30^{\prime} \mathrm{N}$ & $1^{\circ}-5^{\circ} \mathrm{W}$ & 7.51 & 0.025 & 0.15 \\
East Scotland & $55^{\circ} 30^{\prime}-57^{\circ} 30^{\prime} \mathrm{N}$ & $1^{\circ} \mathrm{E}-3^{\circ} \mathrm{W}$ & 6.73 & 0.053 & 0.018 \\
East England & $52^{\circ} 30^{\prime}-55^{\circ} 30^{\prime} \mathrm{N}$ & $3^{\circ} \mathrm{E}-2^{\circ} \mathrm{W}$ & 6.45 & 0.070 & 0.030 \\
Irish Sea & $51^{\circ}-55^{\circ} 30^{\prime} \mathrm{N}$ & $3^{\circ}-8^{\circ} \mathrm{W}$ & 8.65 & 0.040 & 0.059 \\
\hline
\end{tabular}

previous year was assumed to affect kittiwakes through sandeel recruitment (Arnott \& Ruxton 2002). Monthly HadlSST 1.1 data, with a $1^{\circ}$ resolution, were obtained from the British Atmospheric Data Centre and averaged within each region (Fig. 1, Table 1). Mean monthly abundance of Calanus per CPR sample for each region was extracted from the database at the Sir Alister Hardy Foundation for Ocean Science and summarised into 2 covariates. Firstly, we used mean abundance in April to June of the current year. Adult sandeels spend most of the year buried in sandy sediments and feed primarily during these months (Winslade 1974). Secondly, we used mean Calanus abundance in January to August of the previous year as an index of food abundance for larval and juvenile sandeels in their first year of life, when they feed over a longer period than adults. CPR data were too sparse for the West Scotland region to test for effects of Calanus abundance there.

Annual mean breeding productivity in each region was estimated from a mixed model, with a fixed region effect and random colony, year and region $\times$ year effects. The relationships between breeding productivity, SST and Calanus abundance were assessed with linear mixed models, weighted by annual sample size (number of nests monitored). In the first step, we modelled the relationships separately for each region, with random colony and year effects. Subsequently, we constructed an overall hierarchical model, with random colony (nested within region), region, year, and year $\times$ region effects. Because of the hierarchical structure, this model tests for a cross-regional effect of the covariates, i.e. whether annual mean breeding productivity in each region tends to be correlated with each covariate, controlling for consistent regional differences. Non-significant covariates were sequentially eliminated from the models according to type III significance tests with a threshold $\mathrm{p}$ level of 0.1 . An approximate $\mathrm{R}^{2}$ equivalent was calculated as the proportional reduction in the relevant variance components (year for single-region models, region, year and year $x$ region for the overall model) when covariates were included, compared to a pure random effects model. Colony sizes in 1985 to 1988 (from the Seabird Colony Register [SCR] survey; Lloyd et al. 1991) and in 1998 to 2002 (from the Seabird 2000 survey; Heubeck 2004) were extracted from the Joint Nature Conservation Committee database. Colony growth rate was defined as the log-transformed ratio of the Seabird 2000 count to the SCR count. Kettlaness in Shetland was excluded from this analysis because the colony was no longer extant at the time of the Seabird 2000 survey. We tested for relationships between colony growth rate and 1986 to 2004 mean regional values of the environmental covariates (SST and Calanus abundance) in a linear mixed model weighted by the log-transformed SCR count, with random region effects. All analyses were carried out in SAS v 9.1.

\section{RESULTS}

Mean winter SST differed among regions (Table 1, Fig. 2), with the highest temperatures west of Britain, and within the North Sea, higher temperatures in the northern regions than farther south. While winter SST increased in all regions over the study period, the increases were greatest in the North Sea regions, which on average were the coldest (Table 1, Fig. 2). Mean kittiwake breeding productivity differed among the regions $\left(F_{5,69.3}=6.33, \mathrm{p}<0.0001\right.$; Table 2$)$, with the highest value in East England and the lowest in Shetland. Mean colony growth rate between the 2 surveys

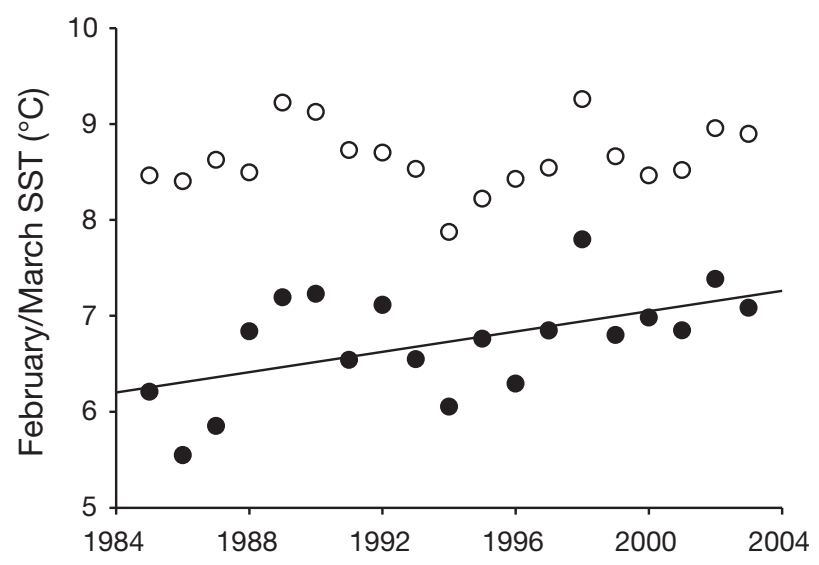

Fig. 2. Mean February/March sea surface temperature in 2 contrasting regions, East (filled symbols) and West Scotland (open symbols), 1985 to 2003. The line shows a significant trend fitted by linear regression (see Table 1) 
Table 2. Rissa tridactyla. Mean breeding productivity (fledged chicks per nest) 1986 to 2004 and mean colony growth rate in each region. Mean colony growth was measured between the Seabird Colony Register and Seabird 2000 surveys and back-transformed to percent growth. One colony in Shetland (Kettlaness) was excluded from the growth rate analysis because it was no longer extant at the time of the Seabird 2000 survey

\begin{tabular}{|lcc|}
\hline Region & $\begin{array}{c}\text { Mean breeding } \\
\text { productivity }\end{array}$ & $\begin{array}{c}\text { Mean growth } \\
\text { rate }\end{array}$ \\
\hline West Scotland & 0.80 & $-16 \%$ \\
Shetland & 0.41 & $-74 \%$ \\
Orkney & 0.93 & $-35 \%$ \\
East Scotland & 0.73 & $-21 \%$ \\
East England & 1.02 & $+13 \%$ \\
Irish Sea & 0.60 & $-35 \%$ \\
\hline
\end{tabular}

differed among the regions $\left(F_{5,41}=5.42, \mathrm{p}=0.0006\right.$; Table 2), ranging from a $74 \%$ decline in Shetland to a $13 \%$ increase in East England. Significant relationships between kittiwake breeding productivity and environmental covariates were found in East Scotland and Orkney (Table 3). In both cases, there was a negative relationship with lagged winter SST, with the estimated slopes being very similar. Calanus abundance in the current year also had significant effects in both regions, although the slope was positive in East Scotland and negative in Orkney (Table 3). The overall analysis, excluding West Scotland where no plankton data were available, showed a marginally non-significant negative effect of lagged winter SST and no effect of Calanus. When data from West Scotland were included, the lagged SST effect became significant (Table 3). The slope associated with lagged winter SST

Table 3. Rissa tridactyla. Slopes and p values for relationships between breeding productivity and 3 environmental covariates. Only effects retained in step-down multiple regression mixed models with a threshold p level of 0.1 are shown. The last column shows an approximate $\mathrm{R}^{2}$ equivalent, calculated as the reduction in relevant variance components when the retained covariates were included in the model (see 'Materials and Methods'). NA: not available

\begin{tabular}{|c|c|c|c|c|c|c|c|}
\hline \multirow[t]{2}{*}{ Region } & \multicolumn{2}{|c|}{ Lagged SST } & \multicolumn{2}{|c|}{$\begin{array}{c}\text { Calanus } \\
\text { same year }\end{array}$} & \multicolumn{2}{|c|}{$\begin{array}{c}\text { Calanus } \\
\text { previous year }\end{array}$} & \multirow[t]{2}{*}{$\begin{array}{c}{ }^{\prime} \mathrm{R}^{2 \prime} \\
\text { (see text) }\end{array}$} \\
\hline & Slope & $\mathrm{p}$ & Slope & $\mathrm{p}$ & Slope & $\mathrm{p}$ & \\
\hline West Scotland & - & - & NA & NA & NA & NA & - \\
\hline Shetland & - & - & - & - & - & - & - \\
\hline Orkney & -0.265 & 0.025 & -0.0300 & 0.0007 & - & - & $65 \%$ \\
\hline East Scotland & -0.280 & 0.025 & 0.0286 & 0.049 & - & - & $38 \%$ \\
\hline East England & - & - & - & - & - & - & - \\
\hline Irish Sea & - & - & - & - & - & - & - \\
\hline $\begin{array}{l}\text { All (excluding } \\
\text { West Scotland) }\end{array}$ & -0.112 & 0.078 & - & - & - & - & $12 \%$ \\
\hline All & -0.112 & 0.044 & NA & NA & NA & NA & $7 \%$ \\
\hline
\end{tabular}

in the overall model was less pronounced than in the 2 regions where this effect was found (Fig. 3). There was a significant correlation between mean colony growth rate and mean breeding success $\left(\mathrm{r}_{s}=0.83, \mathrm{p}=\right.$ 0.042), but no significant relationships were found between colony growth rate and any of the environmental covariates (all $\mathrm{p}>0.2$ ).

\section{DISCUSSION}

We found a negative relationship between kittiwake breeding productivity and SST in the previous winter over both space and time. Breeding productivity tended to be higher following cold winters as well as in regions where winter SST was lower (Fig. 3). This finding complements the results of Frederiksen et al. (2004), who found a strong negative relationship between breeding productivity and lagged winter SST for the well-studied colony at the Isle of May in East Scotland. Thus, although annual mean breeding productivity is not correlated between regions (Frederiksen et al. 2005), our findings suggest that a common driver (winter SST) is at least partly responsible for the extensive spatiotemporal variation. The mechanism behind this relationship is still not clear, but is likely to operate through sandeels, the main prey of kittiwakes during the breeding season. Sandeel recruitment is negatively related to winter SST (Arnott \& Ruxton 2002, ICES 2006), and the pattern that we observed is thus consistent with a dependence on 1-yr-old sandeels for successful breeding of kittiwakes. Shetland was the one region that did not fit the overall pattern, with breeding productivity being lower than expected (Fig. 3). Indeed, when Shetland data were excluded from the overall model, the correlation with lagged winter SST was stronger, but the slope was practically unchanged (slope $=$ $-0.120, \mathrm{p}=0.011$ ).

Previous studies have shown a positive link between copepod biomass in the NW North Sea, the abundance of sandeel larvae and kittiwake breeding productivity on the Isle of May (Frederiksen et al. 2006), and we thus expected positive relationships between kittiwake breeding productivity and Calanus abundance in both the current and the previous year. However, results were inconclusive. Abundance in the current year had the expected positive effect in East Scotland, suggesting 


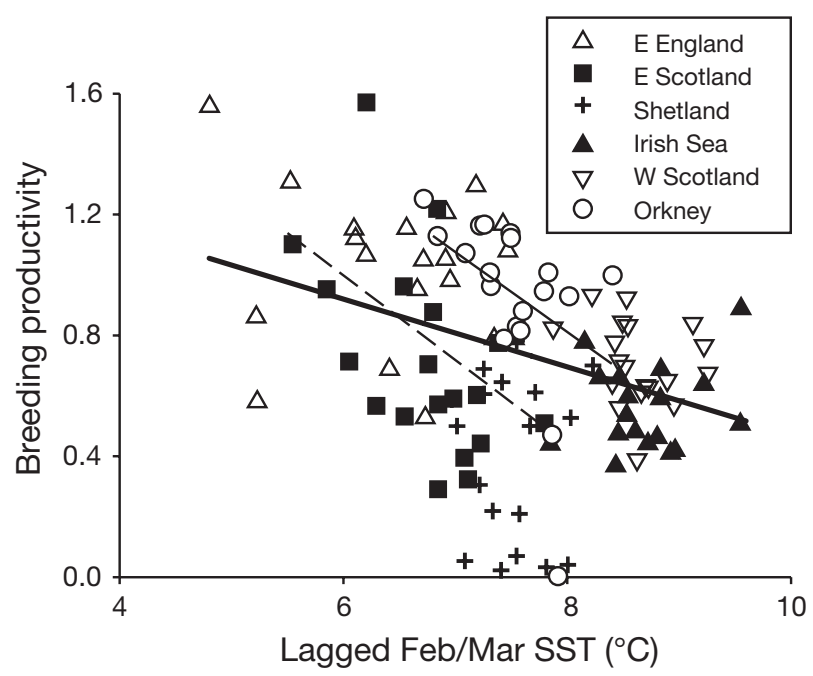

Fig. 3. Rissa tridactyla. Breeding productivity (number of fledged chicks per nest) in 6 British/Irish regions as a function of late winter sea surface temperature in the previous year, 1986 to 2004. For clarity, data points shown are annual leastsquares means for each region; note that the analysis was performed on annual colony means. Regression lines are shown for significant relationships (East Scotland, dashed line; Orkney, solid line; and overall, bold line). For East Scotland and Orkney, the relationships shown are adjusted for Calanus abundance in the current year

greater abundance or availability of sandeels when copepod abundance was high. There was also a strong negative relationship between Calanus abundance and kittiwake breeding productivity in Orkney, a seemingly counterintuitive result confirming earlier findings (Wright \& Bailey 1993). Highlighting such apparent anomalies is important because it emphasises the need to carry out more detailed research to explore processes and mechanisms involved, which are likely to be complex and to vary between regions with contrasting abiotic and biotic conditions (Frederiksen et al. 2007). The previous year's abundance of Calanus was not associated with breeding productivity in any region, possibly suggesting that food abundance during the first year of life in itself had little effect on how many sandeels were available to kittiwakes 1 yr later. A complicating factor may be that the importance of sandeels to breeding kittiwakes may differ between regions. Although North Sea kittiwakes depend extensively on sandeels (e.g. Lewis et al. 2001), very limited data are available on kittiwake diet in West Scotland and the Irish Sea. Dependence on different prey species with different temperature preferences can lead to contrasting relationships with opposing signs between seabird demographic parameters and SST in different regions, as has been shown for Atlantic puffins Fratercula arctica, where adult survival was negatively correlated with SST in 3 colonies where sandeels form the main prey, but positively correlated with SST in a herring-dependent colony (Harris et al. 2005).

Sandeels are also targeted by a large industrial fishery for fishmeal and oil, and an open fishery within kittiwake foraging ranges during the 1990s was associated with depressed breeding productivity in study colonies in East Scotland (Frederiksen et al. 2004, 2007). However, between-region variation in breeding productivity was apparently not related to fishery activity; the only region exposed to large-scale fisheries throughout the study period (East England) had the highest mean breeding productivity, whereas other regions only had a small (Shetland) or no sandeel fishery (Orkney, West Scotland, Irish Sea).

Both mean breeding productivity and mean colony growth rate differed among regions, with numbers in regions with higher mean productivity tending to decline less rapidly. For example, Shetland had both the lowest mean breeding productivity and the greatest observed decline (Table 2). Regional differences in mean colony growth rate thus seemed to be at least partly driven by variation in breeding productivity, implying that other demographic parameters (survival, net dispersal) may be relatively similar among regions at this scale. Nevertheless, regional differences in growth rate were not associated with variation in winter SST or Calanus abundance, although the most productive region and the only one where most colonies had a positive growth rate (East England) also had the lowest winter SST (Fig. 3).

Climate change is a large-scale driver of ecological change, and it is important to understand biological responses at an equivalent scale rather than just at individual study sites. Here, we have shown a negative association between winter SST and an important demographic parameter, kittiwake breeding productivity, both within and across regions of the British Isles. As ocean temperatures around the UK are predicted to warm by a further 2 to $3^{\circ} \mathrm{C}$ over the coming decades (Hulme et al. 2002), this is likely to lead to continued population declines of kittiwakes, which have already declined substantially in the last 15 to 20 yr (Table 2, cf. Mavor et al. 2006). However, trends in sea surface temperatures differ among regions east and west of Britain (Fig. 2), probably linked to their position relative to the European Slope Current and the consequent varying importance of local versus large-scale oceanographic and climatic processes as drivers of local variability (cf. Sharples et al. 2006). Trends in kittiwake populations are thus also likely to continue to vary among regions. The importance of regional variability is forcefully demonstrated by the situation in Shetland, where both breeding productivity and colony growth rate have been much lower than 
in other regions (Table 3, cf. Heubeck et al. 1999), presumably because of low local sandeel recruitment and dependence on advection of sandeel larvae from spawning grounds in Orkney (Wright 1996, Proctor et al. 1998), which may be sensitive to variation in ocean circulation patterns, combined with a lack of alternative prey for kittiwakes (Frederiksen et al. 2007). The widespread network of sites involved in the Seabird Monitoring Programme has proved an extremely useful tool, without which these various patterns would not have been detected, and we strongly recommend that ensuring good regional coverage should be a high priority in national and trans-national monitoring programmes.

Acknowledgements. We are grateful to everyone who collected kittiwake breeding success data as part of the Seabird Monitoring Programme, coordinated by the Joint Nature Conservation Committee in partnership with the Shetland Oil Terminal Environmental Advisory Group and the Royal Society for the Protection of Birds. Thanks to D. Elston for useful statistical advice and to P. Wright for valuable comments. SST data were supplied by the UK Meteorological Office through the British Atmospheric Data Centre.

\section{LITERATURE CITED}

Arnott SA, Ruxton GD (2002) Sandeel recruitment in the North Sea: demographic, climatic and trophic effects. Mar Ecol Prog Ser 238:199-210

Edwards M, Richardson A, Batten S, John AWG (2004) Ecological status report: results from the CPR survey 2002/ 2003. SR104, SAHFOS, Plymouth

Edwards M, Johns DG, Licandro P, John AWG, Stevens DP (2006) Ecological status report: results from the CPR survey 2004/2005. SAHFOS Tech Rep 3:1-8

Frederiksen M, Wanless S, Harris MP, Rothery P, Wilson LJ (2004) The role of industrial fisheries and oceanographic change in the decline of North Sea black-legged kittiwakes. J Appl Ecol 41:1129-1139

Frederiksen M, Wright PJ, Heubeck M, Harris MP, Mavor RA, Wanless S (2005) Regional patterns of kittiwake Rissa tridactyla breeding success are related to variability in sandeel recruitment. Mar Ecol Prog Ser 300:201-211

Frederiksen M, Edwards M, Richardson AJ, Halliday NC, Wanless S (2006) From plankton to top predators: bottomup control of a marine food web across four trophic levels. J Anim Ecol 75:1259-1268

Frederiksen M, Furness RW, Wanless S (2007) Regional variation in the role of bottom-up and top-down processes in controlling sandeel abundance in the North Sea. Mar Ecol Prog Ser 337:279-286

Frederiksen M, Mavor RA, Wanless S (2007) Seabirds as environmental indicators: the advantages of combining data sets. Mar Ecol Prog Ser (in press)

Furness RW, Tasker ML (2000) Seabird-fishery interactions: quantifying the sensitivity of seabirds to reductions in sandeel abundance, and identification of key areas for sensitive seabirds in the North Sea. Mar Ecol Prog Ser 202: 253-264

Harris MP, Anker-Nilssen T, McCleery RH, Erikstad KE, Shaw DN, Grosbois V (2005) Effect of wintering area and climate on the survival of adult Atlantic puffins Fratercula arctica in the eastern Atlantic. Mar Ecol Prog Ser 297: 283-296

Hedd A, Bertram DF, Ryder JL, Jones IL (2006) Effects of interdecadal climate variability on marine trophic interactions: rhinoceros auklets and their fish prey. Mar Ecol Prog Ser 309:263-278

Heubeck M (2004) Black-legged kittiwake Rissa tridactyla. In: Mitchell PI, Newton SF, Ratcliffe N, Dunn TE (eds) Seabird populations of Britain and Ireland. T. \& A.D. Poyser, London, p 277-290

Heubeck M, Mellor RM, Harvey PV, Mainwood AR, Riddington R (1999) Estimating the population size and rate of decline of kittiwakes Rissa tridactyla breeding in Shetland, 1981-97. Bird Study 46:48-61

Hulme M, Jenkins GJ, Lu X, Turnpenny JR and 8 others (2002) Climate change scenarios for the United Kingdom: the UKCIP02 scientific report, Tyndall Centre for Climate Change Research, Norwich

ICES (2006) Report of the Study Group on Recruitment Variability in North Sea Planktivorous Fish (SGRECVAP). ICES CM 2006/LRC:03, International Council for the Exploration of the Sea, Copenhagen

Lewis S, Wanless S, Wright PJ, Harris MP, Bull J, Elston DA (2001) Diet and breeding performance of black-legged kittiwakes Rissa tridactyla at a North Sea colony. Mar Ecol Prog Ser 221:277-284

Lewis S, Grémillet D, Daunt F, Ryan PG, Crawford RJM, Wanless S (2006) Using behavioural and state variables to identify proximate causes of population change in a seabird. Oecologia 147:606-614

Lloyd C, Tasker ML, Partridge K (1991) The status of seabirds in Britain and Ireland. T. \& A.D. Poyser, London

Mavor RA, Parsons M, Heubeck M, Schmitt S (2006) Seabird numbers and breeding success in Britain and Ireland, 2005. UK Nature Conservation Report No. 30, Joint Nature Conservation Committee, Peterborough

Proctor R, Wright PJ, Everitt A (1998) Modelling the transport of larval sandeels on the north west European shelf. Fish Oceanogr 7:347-354

Reay PJ (1986) Ammodytidae. In: Whitehead PJP, Bauchot ML, Hureau JC, Nielsen J, Tortonese E (eds) Fishes of the North-eastern Atlantic and the Mediterranean. UNESCO, Paris, p 945-950

Regehr HM, Montevecchi WA (1997) Interactive effects of food shortage and predation on breeding failure of blacklegged kittiwakes: indirect effects of fisheries activities and implications for indicator species. Mar Ecol Prog Ser 155: 249-260

Reid PC, Colebrook JM, Matthews JBL, Aiken J, Continuous Plankton Recorder Team (2003) The Continuous Plankton Recorder: concepts and history, from Plankton Indicator to undulating recorders. Prog Oceanogr 58:117-173

Sharples J, Ross ON, Scott BE, Greenstreet SPR, Fraser H (2006) Inter-annual variability in the timing of stratification and the spring bloom in the North-western North Sea. Cont Shelf Res 26:733-751

Suryan RM, Irons DB, Kaufman M, Benson J, Jodice PGR, Roby DD, Brown ED (2002) Short-term fluctuations in forage fish availability and the effect on prey selection and broodrearing in the black-legged kittiwake Rissa tridactyla. Mar Ecol Prog Ser 236:273-287

Suryan RM, Irons DB, Brown ED, Jodice PGR, Roby DD (2006) Site-specific effects on productivity of an upper trophic-level marine predator: bottom-up, top-down, and mismatch effects on reproduction in a colonial seabird. Prog Oceanogr 68:303-328 
Tims J, Nisbet ICT, Friar MS, Mostello C, Hatch JJ (2004) Characteristics and performance of common terns in old and newly-established colonies. Waterbirds 27:321-332

Walsh PM, Halley DJ, Harris MP, del Nevo A, Sim IMW, Tasker ML (1995) Seabird monitoring handbook for Britain and Ireland. JNCC/RSPB/ITE/Seabird Group, Peterborough

Wanless S, Frederiksen M, Daunt F, Scott BE, Harris MP (2007) Black-legged kittiwakes as indicators of environmental change in the North Sea: evidence from long-term studies. Prog Oceanogr 72:30-38

Winslade P (1974) Behavioural studies on the lesser sandeel

Editorial responsibility: Howard Browman (Associate Editorin-Chief), Storebø, Norway
Ammodytes marinus (Raitt) I. The effect of food availability on activity and the role of olfaction in food detection. II. The effect of light intensity on activity. III. The effect of temperature on activity and the environmental control of the annual cycle of activity. J Fish Biol 6:565-599

Wright PJ (1996) Is there a conflict between sandeel fisheries and seabirds? A case study at Shetland. In: Greenstreet SPR, Tasker ML (eds) Aquatic predators and their prey. Fishing News Books, Oxford, p 154-165

Wright PJ, Bailey MC (1993) Biology of sandeels in the vicinity of seabird colonies at Shetland. Fisheries Research Report No. 15/93, Marine Laboratory, Aberdeen

Submitted: February 23, 2007; Accepted: June 24, 2007 Proofs received from author(s): October 31, 2007 